\title{
Histopathological and Immunohistochemical Characteristics of Gastrointestinal Stromal Tumors and Risk Group Analysis
}

\author{
Gastrointestinal Stromal Tümörlerin Histopatolojik, \\ Immünhistokimyasal Özellikleri ve Risk Grup Analizi
}

Siddika Findik,

Hasan Esen,

Pembe Oltulu,

Fahriye Kilinc,

Zeliha Celik

Necmettin Erbakan University, Meram Faculty of Medicine, Department of Pathology, Meram/ Konya, Türkiye

Gelis Tarihi/Received: 04 April 2018 Kabul Tarihi/Accepted: 21 May 2018

\begin{abstract}
Öz
Amaç: Gastrointestinal stromal tümörler (GIST); gastrointestinal traktın en sık görülen mezenkimal tümörleridir. Gastrointestinal sistemin peristaltizmini düzenleyen interstisyel Cajal hücrelerinden köken aldıkları düşünülmektedir. Gastrointestinal stromal tümörler farklı morfolojik ve biyolojik davranış özellikleri ile heterojen bir tümör grubudur bu nedenle farklı ülkelerde farklı epidemiyolojik, klinikopatolojik ve prognostik özellikler sergileyebilmektedir. Bu çalışmanın amacı, son 10 yılda GiST tanısı alan 100 olgunun histopatolojik, immünhistokimyasal özellikleri ve risk gruplarının analizini yapmaktır.

Hastalar ve Yöntem: 2006- 2016 yılları arasında patoloji laboratuarımızda GiST tanısı alan 100 olgu retrospektif olarak incelendi. Olguların çap ve mitoz oranlarına göre risk grupları belirlendi. Çap ve mitoz dışındaki histopatolojik ve immünohistokimyasal özellikleri ile risk grupları arasındaki ilişki analiz edildi. Verilerin analizinde Chi- kare- Fischer testleri kullanıldı.

Bulgular: Olgularımızda yaş ve cinsiyet dağılımı risk gruplarına göre değişmemektedir. En çok; sırası ile kolorektal, ekstra gastrointestinal sistem (mezental, omental ve retroperiton), ince barsak ve mide GIST leri yüksek risk grubunda yer almaktadır. Ince barsak, kolorektal ve ekstra gastrointestinal tümörler daha büyük çaplı olup mide tümörleri daha küçük çaplıdır. Immünhistokimyasal CD-34, S-100, SMA, desmin ekspresyonu ile risk grupları ilişkili değildir. Ki-67 \%10' un üzerinde ekspresyon gösteren tümörler yüksek risk grubunda yer almaktadırlar. Mide ve ekstra gastrointestinal tümörler daha fazla CD-34 ekspresyonu göstermektedir. Nekroz ve kanama gösteren tümörler ile selüleritesi yüksek tümörlerin bir üst risk grubunda olma oddsları artmıştır. Ülserasyon, büyüme paterni ve atipi ile risk grupları arasında ilişki mevcut değildir. Sonuç: GIST ler gastrointestinal sistemin nadir tümörlerinden olup farklı bölgelerde, farklı varyasyonlarda ortaya çıkabilirler. GIST lerin histopatolojik ve immünhistokimyasal olarak detaylı incelenmesi ve risk gruplarına göre klasifiye edilmesi klinik tedavi ve takipte önemli rol oynamaktadır.
\end{abstract}

Anahtar Kelimeler: Gastrointestinal stromal tümör, histopatoloji, immünhistokimya, risk grup

\section{Abstract}

Aim: Gastrointestinal stromal tumours (GISTs) are the most common mesenchymal tumours of the gastrointestinal tract. GISTs are thought to originate from the precursors of interstitial Cajal cells which regulate gastrointestinal peristaltism. GISTs include a group of heterogeneous tumors with different morphology and biologic behavior so their epidemiology, clinico-pathological features and prognosis is distinct in different countries. The aim of this study is to analyze the histopathological, immunohistochemical characteristics and risk groups of 100 patients with GIST in the last 10 years in our depertment.

Patients and Methods: Between 2006-2016, 100 patients with GIST diagnosed in our Pathology laboratory were examined retrospectively. Risk groups were determined according to diameter and mitotic rates of the cases. Histopathologic and immunohistochemical features excluding diameter and mitosis were analyzed and the relationship between risk groups was analyzed. A Chi-care- Fischer was used for descriptive statistical analysis.

Results: In our cases, there is no relationship between age, gender and risk groups. Colorectal, extra gastrointestinal system (peritoneum, mesentery and retroperitoneum), small intestine and stomach GISTs are in high risk group respectively. Small intestine, colorectal and extra gastrointestinal system tumors are larger diameter than stomach tumors. There is no relationship between immunohistochemical CD34 , S-100, SMA, desmin and risk groups. Tumors expressing over $10 \%$ of $\mathrm{Ki}-67$ are in high-risk group. Stomach and extra gastrointestinal tumors represent more CD-34 expression. Tumors with necrosis, haemorrhage and high cellularity are at higher risk group. There is no relationship between risk groups and ulceration, growth pattern and atypia.

Conclusions: GISTs are rare tumors of the gastrointestinal tract and may occur in different regions, in different variations. Detailed histopathologic and immunohistochemical examination of the GISTs and classification according to risk group plays an important role in clinical treatment and follow-up.

Keywords: Gastrointestinal stromal tumours, histopathology, immunohistochemistry, risk group

\section{INTRODUCTION}

Gastrointestinal stromal tumors (GIST) are the most common mesenchymal tumors of the gastrointestinal tract (1). GISTs develop from the interstitial cells of Cajal (2). It is estimated that GISTs affect about 1020 million people annually in the whole world (3).
Address correspondence to: Siddika Findik, Necmettin Erbakan University, Meram Faculty of Medicine, Department of Pathology, Meram/ Konya, Türkiye e-mail: drpatolog78@gmail.com

Cite this article as: Findik S, Esen H, Oltulu P, Kilinc F, Celik Z. Histopathological and Immunohistochemical Characteristics of Gastrointestinal Stromal Tumors and Risk Group Analysis. Selcuk Med J 2018;34(3): 100-105
Disclosure: None of the authors has a financial interest in any of the products, devices, or drugs mentioned in this article. The research was not sponsored by an outside organization. All authors have agreed to allow full access to the primary data and to allow the journal to review the data full access to the primary data and to allow the journal to review the data if requested. 
There are findings that some series of GISTs are seen more in males and some have reported that the prevalence of males and females is equal (4). The most common localization is stomach, followed by small intestine, colon, rectum and abdominal cavity. Clinical presentation is very varied and depends on tumor size and localization. GISTs demonstrate 3 cell types as spindle, epithelioid and mixed (spindle and epithelioid) type (5). Estimated $85 \%$ of GIST tumors were found to have an active mutation in the kit proto-oncogene while only $3-5 \%$ mutation in PDGFRA (6). Primary treatment for localized tumors is surgical resection. For advanced stage metastatic tumors, surgical treatment can be performed after neoadjuvant therapy (7).

GISTs are clinically and morphologically variable and may behave in a wide range from benign to malignant. For this reason, it is difficult to predict the biological behavior of the tumor. The most important and easily applicable histological criteria are tumor size (maximum diameter) and mitosis (8-11). Studies have shown that $\leq 5$ mitoses are interpreted in favor of benign behavior, especially in stomach GISTs at 50 high power fields (HPF) (8). Tumors showing $>5$ mitosis in 50 HPF have the high risk for intraabdominal and hepatic metastasis (12). Tumors $2 \mathrm{~cm}$ or less in diameter are also thought to exhibit benign behavior. The use of tumor cellularity and atypia is recommended, but practicability remains a problem (8).

In this study, risk groups were determined according to diameter and mitosis rates of GIST diagnosed cases in our laboratory, the relationship between risk groups and other histopathologic and immunohistochemical features except mitosis and diameter were analyzed.

\section{PATIENTS AND METHODS}

Between 2006 and 2016, 100 patients with GIST diagnosed in our pathology laboratory were retrospectively studied. Surgical resection materials of patients who had not previously received neoadjuvant treatment were included in the study and needle biopsies or cytological materials were excluded from the study. In the cases, distribution according to age, sex, localization, tumor diameter, mitotic activity counts in $50 \mathrm{HPF}$, cell type, growth pattern, atypia, cellularity, necrosis, hemorrhage and ulceration were evaluated. In addition, the immunohistochemical analysis was performed. CD-117, CD-34, a-Smooth Actin (SMA), desmin, S-100 and proliferation indices of Ki-67
Table 1. Fletcher's risk classification.

\begin{tabular}{lll}
\hline Risk group & Tumor Diamater & Mitosis \\
\hline Verylow & $<2 \mathrm{~cm}$ & $<5$ \\
Low & $2-5 \mathrm{~cm}$ & $<5$ \\
Intermedier & $<5 \mathrm{~cm}$ & $6-10$ \\
& $5-10 \mathrm{~cm}$ & $<5$ \\
High & $>5 \mathrm{~cm}$ & $>5$ \\
& $>10 \mathrm{~cm}$ & Anymitosis \\
& Anydiameter & $>10$ \\
\hline
\end{tabular}

immunohistochemical staining were evaluated. The cases were classified according to the risk groups as very low, low, intermedier and high according to tumor diameter and mitotic count (Table-1) (13). The relationship between risk groups and other histopathologic findings and immunohistochemical data except mitosis and diameter were analyzed.

Continuous variables are given as mean \pm std or median (min-max). Categorical variables are given as frequencies and percentages. Fisher and Chi square tests are applied to investigate relationships between categorical variables. A backward ordinal logistic regression model is formed to find out relevant variables with risk group. SAS University Edition 9.4 was used. A p value $<0.05$ is considered significant.

\section{RESULTS}

In the cases the average age is $59.95 \pm 13,76$ and the female to male ratio is equal. $50 \%$ of the cases are localized in stomach, $23 \%$ are small bowel, $17 \%$ are extra gastrointestinal system (extra GIS; peritoneum, mesenteric and retroperitoneal) and $10 \%$ are large intestine. The medyan tumor diameter is $6 \mathrm{~cm}(0,4-35)$. ( $14 \%$ cases $\leq 2 \mathrm{~cm}, 22 \%$ cases $>2-\leq 5 \mathrm{~cm}, 40 \%$ cases $5-10 \mathrm{~cm}$, and $24 \%$ cases $10 \mathrm{~cm})$. The medyan mitosis is 4 (0-220) dür. ( $\leq 5 / 10 \mathrm{HPF}$ (66 cases), 6-10/10 HPF (12 cases), >10/10 HPF (22 cases)) (Table 2). Cell type is $60 \%$ spindle, $12 \%$ epithelioid and $28 \%$ mix. The cases have a mild atypia at $72 \%$ and a severe atypia at $28 \%$. The growth pattern is expansive in $77 \%$ and infiltrative in $23 \%$ of cases. $87 \%$ of the tumors are cellular and $23 \%$ are less cellular. The cases had necrosis in $27 \%$, haemorrhagia in $48 \%$ and mucosal

Table 2. Age, diameter and mitosis analysis in cases.

\begin{tabular}{llllll}
\hline Variable & Mean & Median & Std Dev & $\begin{array}{c}\text { Lower } \\
\text { Quartile }\end{array}$ & $\begin{array}{l}\text { Upper } \\
\text { Quartile }\end{array}$ \\
\hline Age & 59.95 & 61.00 & 13.76 & 50.50 & 70.50 \\
Diameter & 7.57 & 6.00 & 5.59 & 3.75 & 9.50 \\
Mitosis & 9.90 & 4.00 & 24.14 & 2.00 & 7.50 \\
\hline
\end{tabular}


Table 3. Localization and risk groups analysis

\begin{tabular}{lllll}
\hline Localization & Very low/ low & $\begin{array}{l}\text { RiskGroups } \mathbf{n}(\%) \\
\text { Intermedier }\end{array}$ & High & Total \\
\hline Stomach & $23(46)$ & $16(32.0)$ & $11(22)$ & 50 \\
Small Bowel & $7(30.4)$ & $4(17.4)$ & $12(52.1)$ & 23 \\
Large Bowel & $1(10.0)$ & $1(10.0)$ & $8(80.0)$ & 10 \\
Mesentery/omentum & $3(17.65)$ & $2(11.76)$ & $12(70.59)$ & 17 \\
Total & 34 & 23 & 43 & 100 \\
\hline
\end{tabular}

ulceration in $19 \%$. Immunohistochemically CD-34 is $75 \%$ positive, SMA (smooth muscle actin) is $31 \%$, desmin is $12 \%$ and $\mathrm{S}-100$ is $23 \%$. All of the cases are positive with CD-117. The Ki-67 proliferation index is $\leq 10 \%$ at $66 \%$ and $>10 \%$ at $34 \%$ of the cases. $11 \%$ of the cases are very low, $23 \%$ are low, $23 \%$ are intermedier and $43 \%$ are in high risk group.

In the risk group analysis according to age, although younger age groups are more likely to be at high risk groups, they are not statistically significant. While the rate of very low and low risk groups is $42 \%$ at ages 60 over, the rate of intermedier and high risk groups is $50 \%$ at ages 60 and below.

Gender distribution does not depend on risk groups. When localization and risk groups are evaluated, the most common tumors are colorectal, extra GIS, small intestine and stomach localized tumors, respectively in the high-risk group (p: 0.008) (Table 3).

While cell type distribution does not differ in risk groups, the group with the mix-cell type was in the higher-risk group, the epithelioid group is in the mostly low-risk group. There is no significance in the spindle group. Stomach, colorectal and extra GIS localized tumors are mostly spindle and small intestine tumors show more mixed morphology but not statistically significant.

Localization and tumor diameter are related. Colorectal, small intestine and extra GIS located tumors are larger in diameter, stomach-located tumors are less in diameter (p: 0.041) (Table 4).

There is significance only in Ki-67 between immunohistochemical staining and risk groups. $10 \%$ or less expression of Ki-67 are found in the very low and low risk groups and over $10 \%$ of expression are found in the high risk group $(p<0.0001)$ (Table 5). CD-34 and Ki-67 are significant among immunohistochemical stainings according to localization. Stomach and extra GIS derived tumors express more CD-34 ( $p: 0.0002)$. Most colorectal and extra GIS located tumors express Ki-67 more than 10\%, whereas the stomach and small intestine localized tumors express $10 \%$ or less ( $p$ $<0.0001)$. Although there is no significant difference statistically in SMA staining, small intestine-localized tumors show more positive expression (Table 6).

Tumors that have necrosis and hemorrhage and more cellular tumors have increased the odds of being in an upper risk group (Table 7 ).

There was no relationship between the risk groups and the mucosal ulceration, atypia and growth pattern.

\section{DISCUSSION}

GISTs are a heterogeneous group of tumors with different morphological features and biological behavior. For this reason, epidemiology, clinical course and treatment response may vary in different regions (14). GISTs are seen most frequently between the ages of 55 and 65 over the age of 40 (2). In our study, the average age of our patient population was 59.95 and

Table 4. The analysis of tumor localization and diameter

\begin{tabular}{|c|c|c|c|c|c|}
\hline \multirow[t]{2}{*}{ Localization } & \multicolumn{5}{|c|}{ Diameter (cm) } \\
\hline & $\leq 2$ & $2-5$ & $5-10$ & $>10$ & Total \\
\hline \multirow[t]{2}{*}{ Stomach } & 11 & 13 & 21 & 5 & 50 \\
\hline & 22.00 & 26.00 & 42.00 & 10.00 & \\
\hline \multirow[t]{2}{*}{ Small Bowel } & 2 & 6 & 7 & 8 & 23 \\
\hline & 8.70 & 26.09 & 30.43 & 34.78 & \\
\hline \multirow[t]{2}{*}{ Large Bowel } & 0 & 2 & 4 & 4 & 10 \\
\hline & 0.00 & 20.00 & 40.00 & 40.00 & \\
\hline \multirow[t]{2}{*}{ Mesentery/Omentum } & 1 & 1 & 8 & 7 & 17 \\
\hline & 5.88 & 5.88 & 47.06 & 41.18 & \\
\hline Total & 14 & 22 & 40 & 24 & 100 \\
\hline
\end{tabular}


Table 5. Immunohistochemistry-risk group analysis

\begin{tabular}{llcr}
\hline IHC & Very low/low & Risk Groups n (\%) & High \\
\hline CD-34 (+) & $28(37.33)$ & $18(24.0)$ & $29(38.67)$ \\
SMA (+) & $11(35.48)$ & $8(25.81)$ & $12(38.71)$ \\
Desmin (+) & $4(33.35)$ & $4(33.35)$ & $4(33.3)$ \\
S-100 (+) & $8(34.78)$ & $7(30.44)$ & $8(34.78)$ \\
Ki-67(over \%10) & $3(8.82)$ & $3(8.82)$ & $28(82.36)$ \\
\hline
\end{tabular}

found to be in accordance with the literature. Although there was no statistically significant difference in risk group analysis according to age, it was found that 60 and under age group were in higher risk groups than over 60 . There are studies in the literature that have different results on the effect of age on prognosis. In a study of GISTs seen in the Chinese population, it was reported that patients over 60 years of age had a longer survival time (14). However, another study has showed that tumors seen in younger age have better prognosis (15).

There are findings in some series of GISTs that they are seen more in mens and it is said that the prevalence of men and women is equal in some series (4). In our cases, the rates of men and women were found to be equal. There was no difference in gender and risk group analysis. Although there are articles in which GISTs show better prognosis in women (15), there are also articles that show that there is no difference between genders as in our study (14).

GISTs have localized most frequently in stomach (60-70\%), small intestine (25-35\%), colorectal $(5 \%)$ and esophagus $(<2 \%)(16)$. They may also be found in the omentum and the mesentery as primer (16). Peritoneum, mesenteric and retroperitoneal GISTs were grouped as extra GIS in our study. Our cases are located in stomach $(50 \%)$, small intestine $(23 \%)$, exra GIS (17\%) and colorectal location (10\%). The most common location of the stomach and small intestine is consistent with the literature, but colorectal and especially exra GIS cases are higher the mentioned ones. This suggests that some of the extra GIS located tumors that come to our clinic may be a metastatic lesion whose primary is unknown. Esophageal GISTs is not available in our series. This suggests that epidemiologically, GISTs may vary in the frequency of localization in different regions. In the analysis of localization and risk groups, stomach tumors are located in the lowest risk group then the small intestine, extra GIS and colorectal tumors are listed respectively. Findings are consistent with published reports that gastric tumors exhibit less aggressive behavior $(14,17)$.

Two of the most important independent parameters for determining risk groups in GIST are tumor diameter and mitosis. Because the tumor diameter is $\leq 2 \mathrm{~cm}$ and $\leq 5$ mitosis at $50 \mathrm{HPF}$, the tumor is interpreted in favor of showing benign behavior $(4,13)$. We determined the risk groups according to the diameter and mitotic index of our cases. We also reached the conclusion that the tumor diameters differ according to the localizations. We have found that the stomach tumors are smaller in diameter. In the literature, it has been reported that stomach and rectal tumors are smaller, small intestine and colon tumors are larger in size. This finding suggests that the diameter alone may be a significant prognostic indicator and that gastric tumors show less aggressive behavior than other localizations.

Although there is no statistically significant difference between cell type and risk group. But epithelioid cell type tumors are mostly in the low risk group and mixed cell types are mostly in the high risk group in our study. Stomach, colon and extra GIS located tumors are mostly spindle, small intestine tumors show more mixed cell morphology.

Table 6. Localization-immunohistochemistry analysis

\begin{tabular}{lccccc}
\hline Localization & \multicolumn{3}{c}{ Immunohistochemistry } \\
& CD-34(+) & SMA(+) & Desmin(+) & S-100 (+) & Ki-67 (over\%10) \\
\hline Stomach & $46(92.0)$ & $15(30.0)$ & $7(14.0)$ & $9(18.0)$ & $8(16.0)$ \\
Small Bowel & $12(52.17)$ & $11(47.83)$ & $3(13.04)$ & $7(30.43)$ & $7(30.43)$ \\
Large Bowel & $5(50.0)$ & $1(10.0)$ & $0(0.0)$ & $1(10.0)$ & $8(80.0)$ \\
Mesentery/omentum & $12(70.59)$ & $4(23.53)$ & $2(1.76)$ & $6(35.29)$ & $11(64.71)$ \\
\hline
\end{tabular}


Table 7. Odds ratio estimates of cellularity, necrosis and hemorrhage

\begin{tabular}{lllcl}
\hline Effect & & \multicolumn{2}{c}{ Odds Ratio Estimates } & Pr $>$ ChiSq \\
\hline Cellularity & high / low & Point Estimate & $\mathbf{9 5 \%}$ Wald Confidence Limits & 15.938 \\
Necrosis positive/negative & 4.678 & 1.373 & 14.881 & 0.0136 \\
Hemorrhage & 4.370 & 1.283 & 8.738 & 0.0183 \\
\hline
\end{tabular}

Although there are articles in the literature that tumors in the epithelioid cell type are associated with poor prognosis $(18,19)$, there are also articles that higher survival rates of tumors in epithelioid cell type (14). It is currently not possible to use the cell type as an independent parameter.

All of our cases were CD-117 positive, 75\% CD34, 31\% SMA, 23\% S-100 and 12\% desmin positive. A limited number of studies are available on the association between immunohistochemical studies and risk groups. Liang et al. have reported that CD-34 tumors are more aggressive (20). Chirieac et al. have reported that CD-34, SMA, S-100 and desmin expression is not related to surveillance (21). According to Miettinen et al., GISTs are possitive at the ratio of $70-80 \%$ with CD-34 and most common in stomach and small intestine tumors. Esophagus and rectal tumors indicate more CD-34 negative. SMA is positive at the $30 \%$ ratio, most commonly in stomach and small intestine tumors, $\mathrm{S}-100$ is positive at $10 \%$ ratio and commonly in small intestine tumors. Desmin is positive at $2-4 \%$ ratio and most commonly in esophageal GISTs (4). In our cases, CD-34 and SMA positivity is in accordance with the literature and we have high S-100 and desmin staining rates. Stomach and extra GIS located tumors are more CD-34 positive in our series. This finding may be due to greater of our extra GIS located tumor count compared to the series in the literature. Further studies involving more extra GIS located tumors may be needed. SMA positivity was detected most commonly in small intestine tumors. We could not comment on esophageal tumors because we did not have esophageal tumor in our series.

Tumors with an immunohistochemical Ki-67 ratio of $10 \%$ or less are located in the very low and low risk group, and the cases showing the over $10 \%$ expression are located in the high risk group. In addition, tumors of the stomach and small intestine showed lower Ki67 expression. In the literature, cases showing Ki-67 positivity above $10 \%$ were reported to be associated with metastasis and tumor-associated deaths. In our series, the stomach and then small intestine tumors are located in the low-risk group, this is also consistent with our $\mathrm{Ki}-67$ ratios. It is stimulating that $\mathrm{Ki}-67$ rates should be included in pathology reports.

In our study, the rates of being in an upper-risk group of tumors with necrosis and haemorrhagia and tumors with high cellularity were found to be high. However, no correlation was found between risk groups and mucosal ulceration, atypia, and tumor growth pattern. There are articles in the mentioned histopathological features literature that invasive growth pattern, necrosis and mucosal ulceration are associated with poor prognosis (22). In a study that classified GISTs as benign and malignant according to mitosis and diameter and that clearly defined the tumors that could not enter the benign and malign categorization as borderline, borderline tumors showing invasive growth pattern, necrosis and cytologic atypia were the aggressive course (23).

In summary; we classified our cases according to their diameter and mitotic rates. We assessed whether there was any association between risk groups and features such as age, sex, tumor location, cell type, cell atypia, cellularity, growth pattern, necrosis, hemorrhage, mucosal ulceration and immunohistochemical findings. In conclusion, GISTs are a heterogeneous group of tumors with different morphological features and biological behaviors and may differ in terms of histopathological and immunohistochemical characteristics affecting the epidemiological and risk group. More studies involving more cases in different regions will be needed. Histopathologic features and immunohistochemical findings other than diameter and mitosis should be included in the pathology reports in order to guide the clinician and to provide a prognosis in the risk classification.

Conflict of interest: Authors declare that there is no conflict of interest between the authors of the article.

Financial conflict of interest: Authors declare that they did not receive any financial support in this study.

Address correspondence to: Siddika Findik, Necmettin Erbakan University, Meram Faculty of Medicine, Department of 
Pathology, Meram/ Konya, Türkiye

e-mail address: drpatolog78@gmail.com

Phone: 5052159005

\section{REFERENCES}

1. Laurini JA, Carter JE. Gastrointestinal stromal tumors: A review of the literature. Arch Pathol Lab Med 2010;134:13441.

2. Miettinen M, Lasota J. Gastrointestinal stromal tumors-de nition, clinical, histological, immunohistochemical, and molecular genetic features and differential diagnosis. Virchows Arch 2001;438:1-12.

3. Goettsch WG, Bos SD, Breekveldt-Postma N, et al. Incidence of gastrointestinal stromal tumours is underestimated: Results of a nation-wide study. Eur J Cancer 2005;41:286872.

4. Miettinen M, Majidi M, Lasota J. Pathology and diagnostic criteria of gastrointestinal stromal tumors (GIST's): A review. Eur J Cancer 2002;5:39-51.

5. Patil DT, Rubin BP. Gastrointestinal stromal tumor: Advances in diagnosis and management. Arch Pathol Lab Med 2011;135:1298-310.

6. Dematteo RP, Ballman KV, Antonescu CR, et al. Adjuvant imatinib mesylate after resection of localised, primary gastrointestinal stromal tumour: A randomised, double-blind, placebo-controlled trial. Lancet 2009;373:1097-104.

7. Date RS, Stylianides NA, Pursnani KG, et al. Management of gastrointestinal stromal tumours in the Imatinib era: A surgeon's perspective. World J Surg Oncol 2008;6:77;1-4.

8. Emory TS, Sobin LH, Lukes L, et al. Prognosis of gastrointestinal smooth-muscle (stromal) tumors: Dependence on anatomics ite. Am J Surg Pathol 1999;23:827.

9. Franquemont DW. Differentiation and risk assessment of gastrointestinal stromal tumors. Am J Clin Pathol 1995;103:41-7.

10. Lerma E, Oliva E, Tugues D, et al. Stromal tumours of the gastrointestinal tract: A clinicopathological and ploidy analysis of 33 cases. Virchows Arch 1994;424:19-24.

11. Rudolph P, Gloeckner K, Parwaresch $R$, et al. Immunophenotype, proliferation, DNA-ploidy, and biological behavior of gastrointestinal stromal tumors: A multivariate clinicopathologic study. Hum Pathol 1998;29:791-800.

12. Miettinen $M$, Sarlomo-Rikala $M$, Sobin $L H$, et al. Gastrointestinal stromal tumors and leiomyosarcomas in the colon: A clinicopathologic, immunohistochemical and molecular genetic study of 44 cases. Am J Surg Pathol 2000;24:1339-52.

13. Fletcher CDM, Berman JJ, Corless C, et al. Diagnosis of gastrointestinal stromal tumors: A consensus approach. Hum Pathol 2002;33:459-65.

14. Li J, Zhang $\mathrm{H}$, Chen $\mathrm{Z}$, et al. Clinicopathological characteristics and prognostic factors of gastrointestinal stromal tumors among a Chinese population. Int J Clin Exp Pathol 2015;8(12):15969-76.

15. Kramer K, Knippschild U, Mayer B, et al. Impact of age and gender on tumor related prognosis in gastrointestinal stromal tumors (GIST). BMC Cancer 2015;15;1-10.

16. Miettinen M, Monihan JM, Sarlomo-Rikala M, et al. Gastrointestinal stromal tumors/smooth muscle tumors/ GISTs in the omentum and mesentery - clinicopathologic and immunohistochemical study of 26 cases. Am J Surg Pathol 1999;23:1109-18.

17. Ueyama T, Guo K-J, Hashimoto H, et al. A clinicopathologic and immunohistochemical study of gastrointestinal stromal tumors. Cancer 1992;69:947-

18. Kim KM, Kang DW, Moon WS, et al. Gastrointestinal stromal tumors in Koreans: It's incidence and the clinical, pathologic and immunohistochemical findings. J Korean Med Sci 2005;20:977-84.

19. Koay MH, Goh YW, lacopetta B, et al. Gastrointestinal stromal tumours (GISTs): A clinicopathological and molecular study of 66 cases. Pathology 2005;37:22-31.

20. Liang YM, Li XH, ChenW. [Rolesofriskassessmentand Ki67 index in judging prognostic of gastrointestinal stromal tumors]. Zhonghua Yi Xue Za Zhi 2008;88:1041-5.

21. Chirieac LR, Trent JC, Steinert DM, et al. Correlation of immunophenotype with progression-free survival in patients with gastrointestinal stromal tumors treated with imatinib mesylate. Cancer 2006;107:2237-44.

22. Loria N, Sawaya RA, Friedenberg FK. Review article: The biology, diagnosis and management of gastrointestinal stromal tumours. Aliment Pharmacol Ther 2014;39:1376-86.

23. Yan H, Pierre Marchettini P, Yair I, et al. Sugarbake. Prognostic assessment of gastrointestinal stromal tumor. Am J Clin Oncol 2003;26(3):221-8. 